\title{
Studies on Zooplankton Diversity of Western Ramganga River in Almora (Uttarakhand) India
}

\author{
Anupama Pandey ${ }^{1}$, Hem Chandra Upadhyay ${ }^{2}$ \\ ${ }^{1,2}$ Department of Zoology, R. H. Govt. P.G. College Kashipur,(U.K.) India
}

\begin{abstract}
Zooplankton community structure and organization play a vital role in aquaculture and capture fisheries. The present paper is devoted to the findings on group composition, community abundance and relative group abundance, species diversity, etc. of zooplankton community in response to evolution of the river. The distribution, abundance, population, group percentage and species diversity were studied in the river and correlated with pollution indicating water quality characteristics.
\end{abstract}

Keywords: Species Diversity, Western Ramganga River, Zooplankton

\section{Introduction}

Zooplankton are an important biotic component influencing all the functional aspects of every type of aquatic ecosystems viz. food chains, food webs, energy flow and cycling of matter. Zooplankton constitute the second trophic level in aquatic media and they efficiently consume the primary production. Zooplankton are connecting link between producers and successive levels of consumers. Zooplankton plays an integral role and serves as bio-indicator therefore they are a well suited tool for understanding water pollution status. Zooplankton feeds phytoplankton, detritus, bacteria, and other heterotrophic organisms. The rate of zooplankton feeding varies highly seasonally and spatially among rivers. Feeding can remove large portions of the phytoplankton at a particular time and can cause a marked reduction in phytoplankton population and productivity. Variations in zooplankton community impart a limiting effect on phytoplankton populations. Mackas, et al, (2001) found zooplankton are excellent organisms for the study of an aquatic ecosystem and respond quickly to climate variability because their short life cycle. Various environmental factors that determine the characters of water have great importance upon the growth and abundance of zooplankton (Jose and SanalKumar, 2012). The qualitative and quantitative estimation of plankton have been utilized to assess the quality of water. Generally, climatic variation, altitude ranges associated with the alignment that determine the altitudinal growth and variety of vegetation. Thus, this study might also be important from the altitudinal variation perspective.

\section{Material and Methods}

The present study was carried out in $45 \mathrm{~km}$ stretch of Western Ramganga River at three sampling sites, namely Gairsen (S1), Chaukhutiya (S2) and Masi (S3) in Almora district of Uttarakhand (Fig: 1). The study area, is located between $29^{\circ} 36^{\prime} \mathrm{N}$ latitude and $79^{\circ} 30^{\prime} \mathrm{E}$ longitude in the Western part of Central Himalaya.

Zooplankton samples were collected by filtering $50 \mathrm{~L}$ of water through plankton net with demarcating collecting tube. All organisms were represented numerically as units per liter of water. Three samples were counted and the average was taken to calculate the number of organisms per liter.

$$
\mathrm{n}=\frac{(\mathrm{a} \times 1,000) \mathrm{C}}{\mathrm{L}}
$$

Where:

$\mathrm{n}=$ number of plankton per liter of original water

$\mathrm{a}=$ average no. of plankton in all counts in counting unit of a ml capacity

$\mathrm{C}=$ volume of original concentrate in $\mathrm{ml}$.

$\mathrm{L}=$ volume of original water filtered expressed in liter.

Diversity index: Species diversity index of biotic communities was calculated by using Shannon-Wiener information function which is:

$$
\bar{H}=-\sum_{i=1}^{S} P i \log _{2} P i \text {, and }
$$

Concentration of dominance was calculated by using Simpson's index which is given below:

$$
\mathrm{C}=\sum_{i=1}^{s}(P i)^{2}
$$

Where $\mathrm{H}^{\prime}$ is the diversity index; ln is the natural logarithm; $\mathrm{i}$ is an index number for each species present in a sample; pi is the number of individuals within a species (ni) divided by the total number of individuals $(\mathrm{N})$ present in the entire sample.

To estimate monthly variations in zooplankton community, the average data of all sampling stations were used as replicates. That data finally used as monthly average value for computation of further observations.

\section{Results and Discussion}

During the entire study period (i.e. Jan., 2012 to Dec., 2012), 14 zooplankton species were recorded in the collection. Identified zooplankton species belonged to three taxonomic groups namely Rotifera, Protozoa and Crustacea. Rotifera was dominant group and contributed about $43 \%$ to the total zooplankton number (Fig 2). Similar observations had been made by some researchers such as Akin-Oriola, (2003) and Imoobe and Adeyinka, (2010). Basinska and Kippen, (2009) attributed that the rotifer community structure depends on physico-chemical factors as well as biological factors like predation or competition. The group Protozoa ranked second in terms of percentage share of the zooplankton density with 


\section{International Journal of Science and Research (IJSR) \\ ISSN (Online): 2319-7064}

Index Copernicus Value (2013): 6.14 | Impact Factor (2015): 6.391

about $39 \%$ part in the community. The present investigation, is in agreement with the observations made by (Negi and Negi, 2010; Kanwal and Pathani, 2012; Gholap, 2014).

In addition to this $18 \%$ of share of the total zooplankton number was of Crustacean. This group shared least population to the total zooplankton standing crop in the river.Poor density of Crustaceans in the river could be attributed to high predation pressure by fishes.

In present investigation, zooplankton are abundant during the slow water current, while the fast water current brings about a sharp decline in their density. Similar observation has been reported by (Pennak, 1946).

Species diversity is a unique characteristic of biological organization at the community level.Zooplankton species composition and diversity give an insight into the characteristics and quality of the water.Ramesha and Sophia, (2013) in their studies reported that a diversity index greater than 3 indicates clean water and between 1 to 3 indicates moderately polluted water while values less than 1 is characteristic of heavily polluted water. The species diversity and dominance indices of zooplankton community for the entire study period (January, 2012 to December, 2012) are shown in figure 3 . The mean Shannon-Weiner diversity of zooplankton biocoenosis in Western Ramganga River ranged from a minimum of 1.099 (July and August) and a maximum of 2.482 (October) and the concentration of dominance varied from 0.089 (October) to 0.333 (July and August) during the entire study period figure 3 .

\section{Conclusion}

Overall, the present research revealed that none of the pollution indicator species of zooplankton was characteristically present in higher number. Therefore, it can be concluded from these results that the conditions in Western Ramganga River system are suitable for the development and management of aquaculture resources.

\section{References}

[1] Akin-Oriola, F.A. 2003. Zooplankton associations and environmental factors in Ogunpa and Ona Rivers, Nigeria. Rev. Biol. Trop, 51(2): 391- 398.

[2] Basinska, A. and Kuczynska-Kippen 2009. J. Biologia. Biomedical and life sciences, 1100-1107.

[3] Gholap, Avinash B. 2014. Species diversity indices of zooplankton from Sadatpur reservoir, Ahmednagar, Maharashtra Annals of Biological Research, 5 (4): 5861.

[4] Imoobe, T.O.T. and Adeyinka, M.L. 2010. Zooplankton-based assessment of the trophic state of a tropical forest river. International Journal of Fisheries and Aquaculture, (I.J.F.A), 2(2): 64-70.

[5] Jose, R. and Sanalkumar, M.G. 2012.Seasonal Variations in the Zooplankton Diversity of River Achencovil. International Journal of Scientific and Research Publications. 2(11): 1-5.

[6] Kanwal, B.P.S. and Pathani, S.S. 2012. Plankton diversity in some tributaries of river Suyal of Kumaun
Himalaya, International Journal of Innovations in BioSciences, 2 (3): 146-153.

[7] Mackas, D.L., Thomson, R.R. and Galbraith, M. 2001 Changes in the zooplankton community of the British Columbia Continental margin, 19851999, and their Conversation with Oceanographic conditions. Can. J. Fish. Aquat. Sci., 58: 685-702.

[8] Negi, R.K. and Negi, T. 2010. Diversity of zooplanktons in the Hinval freshwater stream at Shivpuri (Garhwal region), Uttarakhand. J. Env. Bio. Sci., 24(2): 167-169.

[9] Pennak, R.W. 1946. The dynamics of fresh water plankton populations Ecological Monographs, 16(4): 340-355.

[10] Ramesha, M.M. and Sophia, S. 2013. Species composition and diversity of Plankton in the River Seeta at Seetanadi, the Western Ghats, India. Advanced Bio. Tech., 12(8): 2319-6750.

\section{LEGENDS TO FIGURES-}

Fig 1: Map showing location of selected sampling stations on Western Ramganga River

Fig 2: Percent composition of various groups of zooplankton in terms of density

Fig 3: Mean community abundance of zooplankton in Western Ramganga River

Fig 4: Mean species diversity of zooplankton in Western Ramganga River

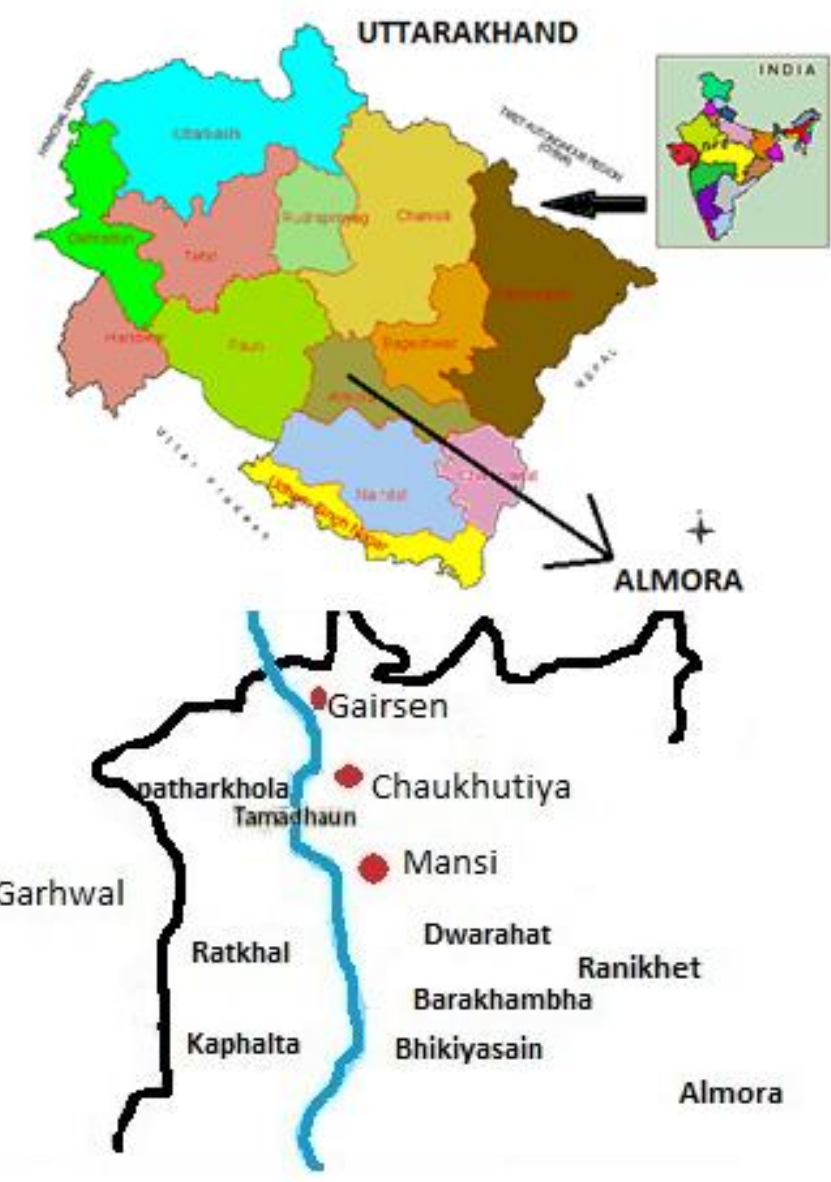

Figure 1: Map showing location of selected sampling stations on Western Ramganga River (Map not to scale) 


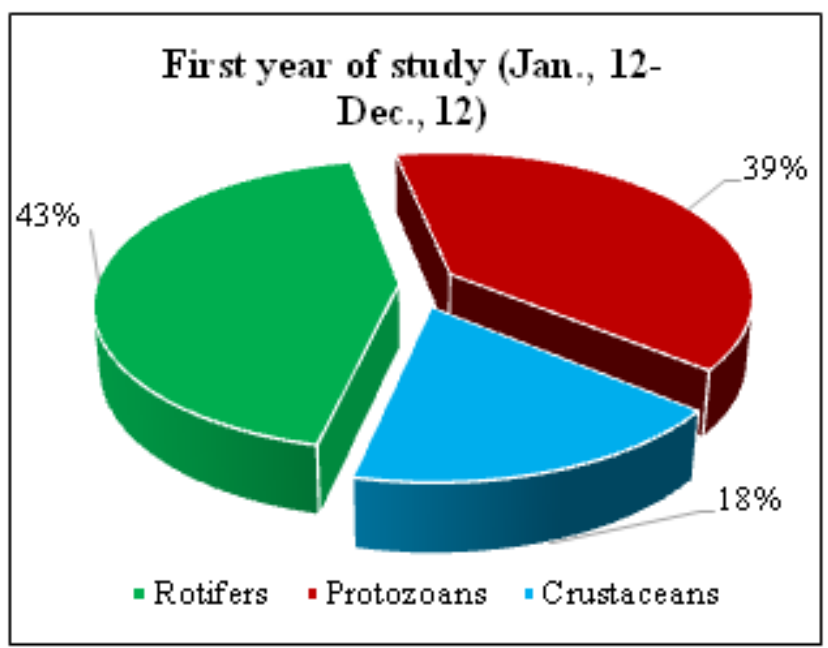

Figure 2: Comparison of percent composition of various groups of zooplankton in terms of density

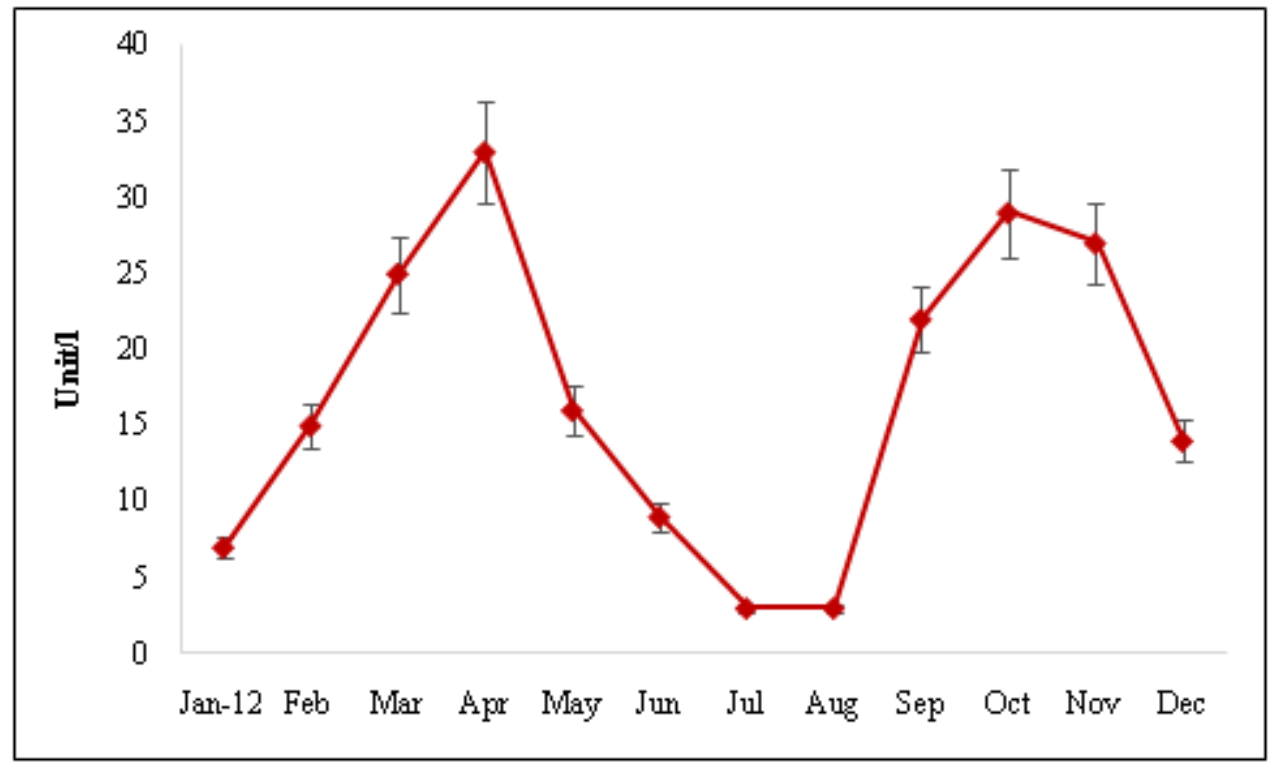

Figure 3: Seasonal variations in mean community abundance of zooplanktons in Western Ramganga River(vertical bars represents standard deviation of the mean)

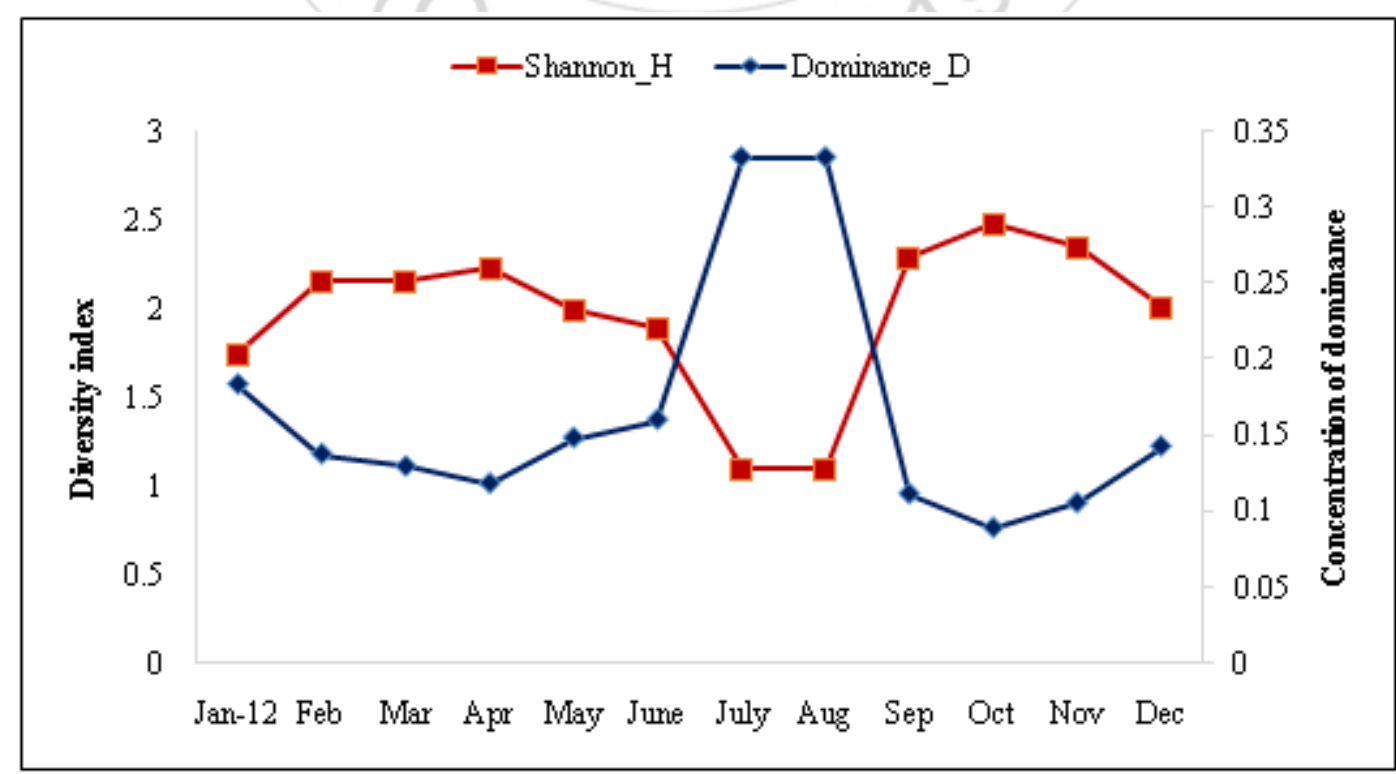

Figure 4: Seasonal variations in mean Shannon-Weiner diversity index and concentration of dominance of zooplankton in Western Ramganga River

\section{Volume 5 Issue 5, May 2016}

$$
\text { www.ijsr.net }
$$

